\title{
SYNONYMY OF LEONOMYRMA ARNOLDI 1968 \\ WITH CHALEPOXENUS MENOZZI 1922 \\ (HYMENOPTERA: FORMICIDAE)*
}

\author{
By Alfred Buschinger \\ Institut für Zoologie, Fachbereich Biologie, \\ der Technischen Hochschule, D 6100 Darmstadt, \\ Federal Republic of Germany.
}

Arnoldi (1968) erected the genus Leonomyrma for a single new species, L. spinosa, which he had collected in July, 1949, near Peremetriaja, East-Kasachstan (USSR), at the lower course of Ural River. Up until present, only the type series of 4 우 and $14 \hat{\sigma} \widehat{o}$ have been known; no $\not \varnothing \phi$ were found. In the course of a study in morphology and behavior of several species of the ant genus Chalepoxenus, I came across the description of Leonomyrma. A direct comparison of its holotype (O) and an allotype ( $\hat{O})$ with material of two Chalepoxenus species, C. muellerianus (Finzi) $(=C$. gribodoi Menozzi) and C. kutteri Cagniant, clearly revealed the synonymy of the two genera.

\section{Genus Chalepoxenus}

Chalepoxenus Menozzi, 1922: 257, worker, female. Type species by original designation: $C$. gribodoi.

Leptothorax (Temnothorax) muellerianus Finzi, 1921: 118, synonymized with Chalepoxenus by Müller 1923: 98.

C. gribodoi Menozzi, 1922: 257, synonymized with C. muellerianus (Finzi) by Kutter (1973).

Leonomyrma Arnoldi, 1968: 1809, female, male. Type species: L. spinosa, monobasic. NEW SYNONYMY.

Since the original description of Leonomyrma was published in Russian, I provide an English translation of its main contents:

"Leonomyrma K. Arnoldi gen. n. (Leptothoracini)"

"Type of the genus: Leonomyrma spinosa K. Arnoldi sp. n. Female: Head elongate rectangular. Antennae 12-jointed,

*Manuscript received by the editor August 14, 1986. 
mandibles triangular with dentate masticatory border. Frontal carinae long and straight, not forming scrobes for hiding the antennal scapes. Epinotum with two long spines. Petiolar nodes rounded above, low, petiole with a conspicuous ventral tooth, postpetiole with a long spine. The femora somewhat swollen. Erect hairs of the body long, fine, pubescence only present in legs and scapes. Wings with reduced venation, with a long, closed cubital cell.

"Male: Antennae 13-jointed, the long, slender scape overreaching the occipital margin, club 4-segmented, not shorter than the remainder of the funiculus. Eyes very large, convex. Masticatory border of mandibles dentate. Thorax narrow, with Mayrian furrows and strong epinotal spines. Hairs and wings as in the female."

The description of the new species, $L$. spinosa, contains some measurements of the holotype ?:

"Head length $0.85 \mathrm{~mm}$, width 0.70 , scape length 0.60 , length of eye 0.30 , thorax length 1.15 , width 0.60 , height 0.70 , length of petiole 0.30 , width 0.29 , height without ventral tooth 0.36 , postpetiole length 0.30 , width $0.47 \mathrm{~mm}$.

"Female: Head elongate, 1.5 times longer than wide, with nearly straight lateral margins, with distinct anterior and more rounded posterior corners. Eyes much larger than the genae. Clypeus moderately vaulted, slightly concave in the middle of the anterior margin, with an indistinct central carina. Frontal triangle impressed, smooth, indistinctly confined. Antennal club 3-segmented, only slightly shorter than the remainder of the funiculus. Last segment (like in the male) about the length of the two preceding ones together. Scape not fully reaching the occipital margin. Segment 3 to 7 of funiculus wide, not longer than wide. The long frontal carinae reaching behind the hind margin of the eyes. Thorax slender, elongate, somewhat flat above, anterior part of mesonotum narrowing, not covering the pronotal shoulders. Epinotal spines strong, longer than half their basal distance. Petiole short, massive, in profile with descending anterior and rounded upper surface, with a big tooth below. Postpetiole with a fingerlike spine. Dorsal side of 


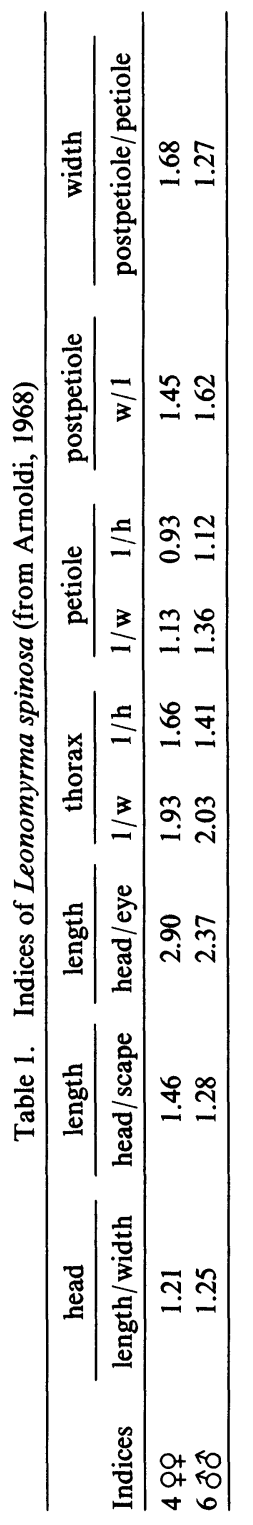



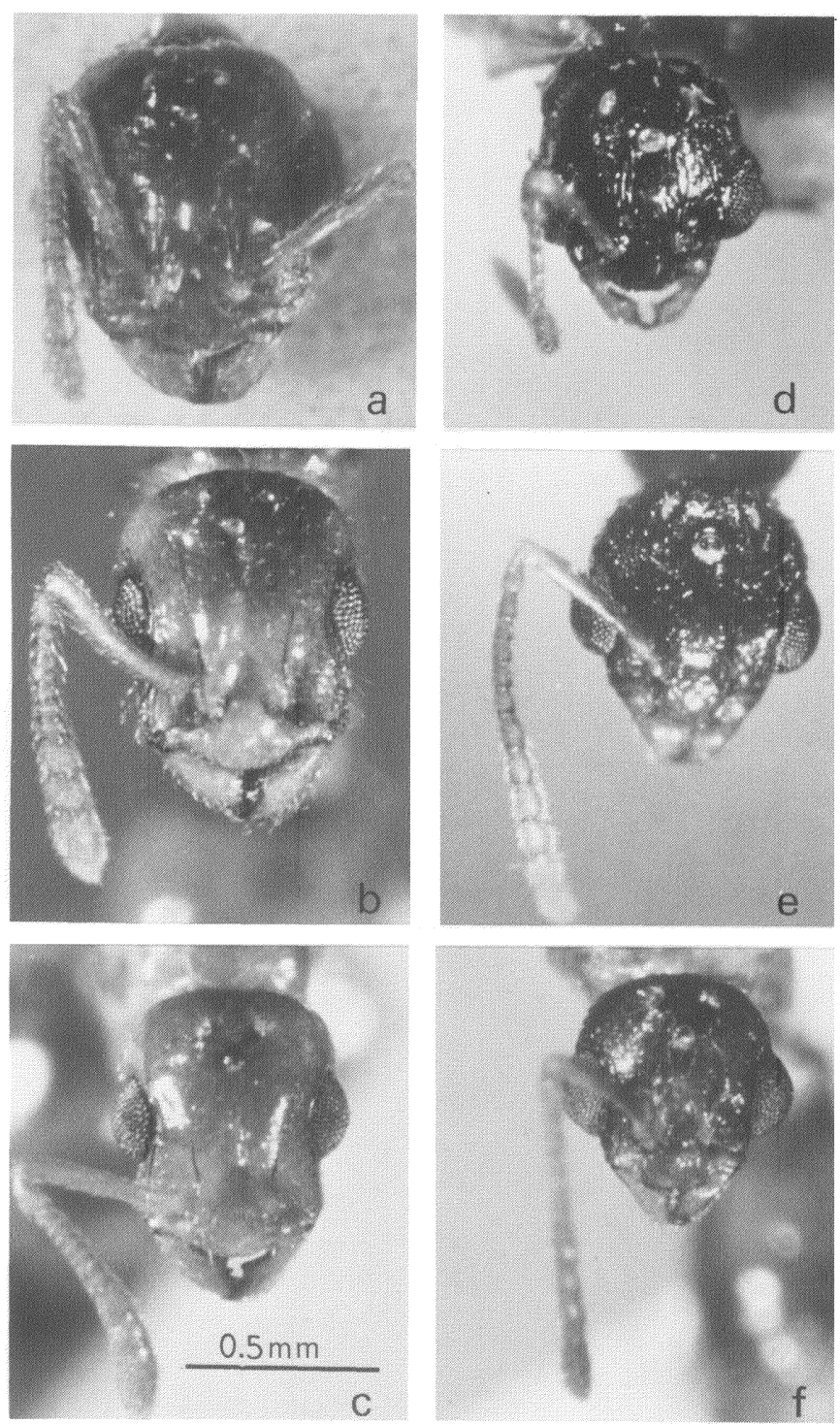

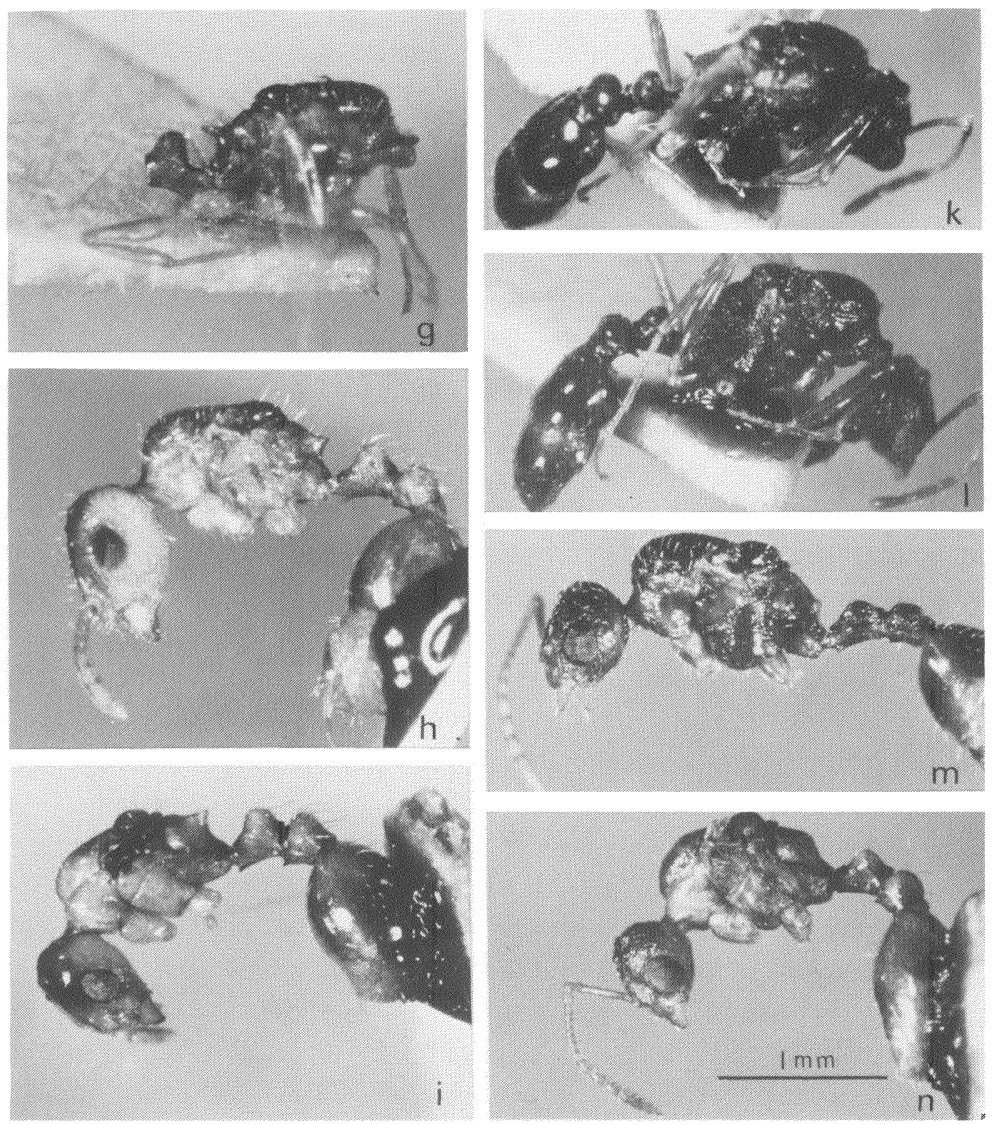

Fig. 1. (Facing page and above.) Heads and lateral views of Chalepoxenus spinosus (nov. comb.) (a, $\mathrm{g}-\mathrm{O} ; \mathrm{d}, \mathrm{k}, \mathrm{l}-\hat{\mathrm{O}}$; in $\mathrm{k}$ an epinotal spine, and in 1 the postpetiolar spine are clearly visible), $C$. muellerianus $(\mathrm{b}, \mathrm{h}-\mathrm{O} ; \mathrm{e}, \mathrm{m}-\hat{\mathrm{o}})$, and C. kutteri (c, i-o; f, n- $-\hat{O}$ ). Pictures were taken with a Wild Photomakroskop M 400 . 
alitrunk with very long, not dense hairs, which are more developed in the petioles and the gaster. Tibiae and scapes with sparse (not in all specimens preserved) outstanding hairs and a fine pubescence which is mostly lacking in other body parts. Body shining, head and thorax with long, sparse, longitudinal wrinkles, one particularly long wrinkle along the inner margin of the eye. Petioles smooth, gaster very smooth and shining. Light brown, gaster and top of the head brown, 3.75-3.95 mm.

"Male: Head elongate, 1.25 times longer than wide, with slightly vaulted sides and very large, very convex eyes. Antennal clubs with very long segments, all funicular segments much longer than wide. Clypeus elongate, reaching behind the genae, its anterior border blunted in the middle, vaulted, smooth like the triangular frontal area. Frontal carinae straight, parallel, visible until the anterior ocellus, all ocelli very large. Thorax narrow above, anterior part of mesonotum narrowing. Alitrunk shining, with sparse longitudinal wrinkles, petioles smooth, with ventral teeth as in the $\&$, but smaller. Hypopygium and squamulae long, leaf-shaped. Brown, legs and antennae straw-yellow. 3.3-3.7 mm."

A comparison is made with other leptothoracine genera, and the author stresses that Leonomyrma exhibits some characters of social parasitic ants. Thus, the ventral projections of the petioles appear similar to those in Formicoxenus, the long frontal carinae resemble those of Chalepoxenus, the structure of the male antenna and the wing venation are said to match those of Myrmoxenus, to which Leonomyrma is closely related. It differs, however, from Myrmoxenus by the dentate mandibles of males and the queens, the strong epinotal spines, the rounded nodes, and the long and fine postpetiolar spine. From Formicoxenus it is distinguished by the number of antennal segments, shape of head, etc.; from Chalepoxenus by lacking the long scrobes along the frontal carinae, much stronger epinotal spines, and the long hairs; and from Epimyrma also by the long hairs, number of antennal segments, and so on.

Thus, the most important difference between Leonomyrma and Chalepoxenus refers to the antennal scrobes, since size and shape of epinotal spines and the density and length of hairs usually are characters varying widely within one genus. In the original description of 
Chalepoxenus, however, Menozzi (1922) explicitly writes: "frontal carinae long, sub-parallel, and laterally confining an antennal scrobe, which is little marked and much shorter than the antennal scape" (translated from Italian). Direct comparison (Fig. 1) reveals that there is literally no difference between the antennal scrobes of Leonomyrma and Chalepoxenus.

In table $2 L$. spinosa is compared with two Chalepoxenus species. I choose for reference $C$. muellerianus and $C$. kutteri, because they represent the two most different species in the genus. $C$. siciliensis and $C$. insubricus closely resemble $C$. muellerianus, $C$. gribodo $i$ was already synonymized with the latter (Kutter 1973), and C. tramieri is close to C. kutteri (Cagniant 1983).

The comparison shows that there are some morphological differences between $L$. spinosa and Chalepoxenus species, but not more than between the latter two. L. spinosa is sharing some characters (postpetiolar spines in $\widehat{\sigma}$ and $q$, long and acute epinotal spines in $q$, long body hairs) with C. kutteri, others (steeply ascending petiolar node, erect tibial hairs) with $C$. muellerianus. No crucial differences could be found which would justify the maintenance of a separate genus for $L$. spinosa, whereas its species rank in the genus Chalepoxenus appears sufficiently substantiated.

Since $C$. muellerianus is an active slavemaker (Ehrhardt 1980), and also $C$. siciliensis, $C$. insubricus, and $C$. kutteri (Buschinger et al., in prep.), we may predict that $L$. spinosa, too, will exhibit this particular life habit. The original material consists of alate sexuals, only, which were apparently caught during swarming. The lack of workers in the sample, therefore, is not surprising*.

\section{SUMMARY}

The monotypical genus Leonomyrma, described by Arnoldi 1968 from 4 우 and $14 \hat{\partial} \hat{\partial}$ of $L$. spinosa from East-Kasachstan, USSR, is

*Chalepoxenus brunneus Cagniant 1985, described from males and females from one colony, is a workerless and thus not a slave-raiding species. We (A. Buschinger, J. Heinze, H. Cagniant, X. Espadaler) collected 11 colonies at its type locality, Tizi-n-Test, Great Atlas of Morocco, on May 6, 1987. None of them contained Chalepoxenus workers, and their brood also consisted of male and female pupae only. Thus, $C$. spinosus also might be truly workerless. [Added in proof, May, 1987]. 


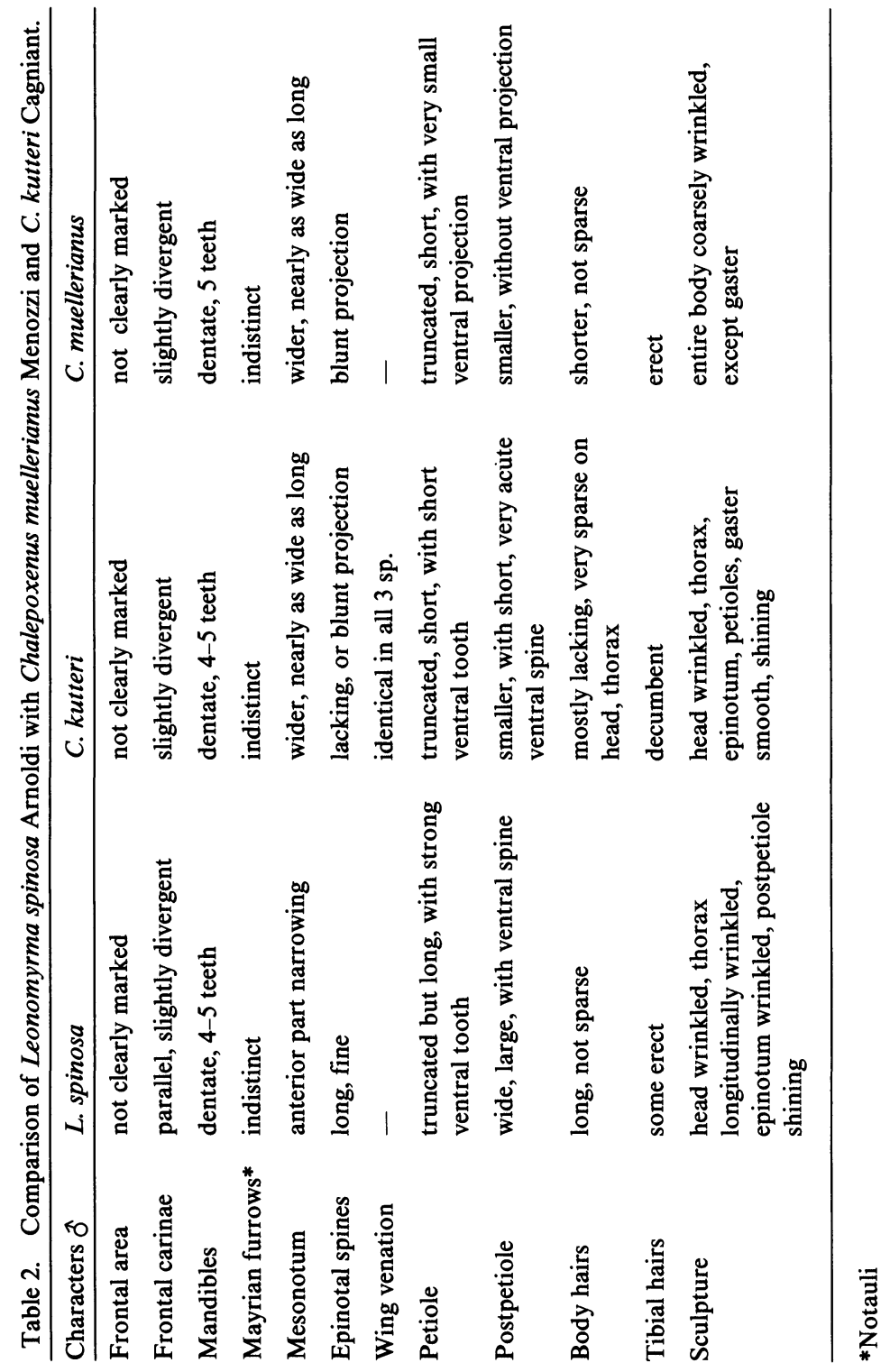




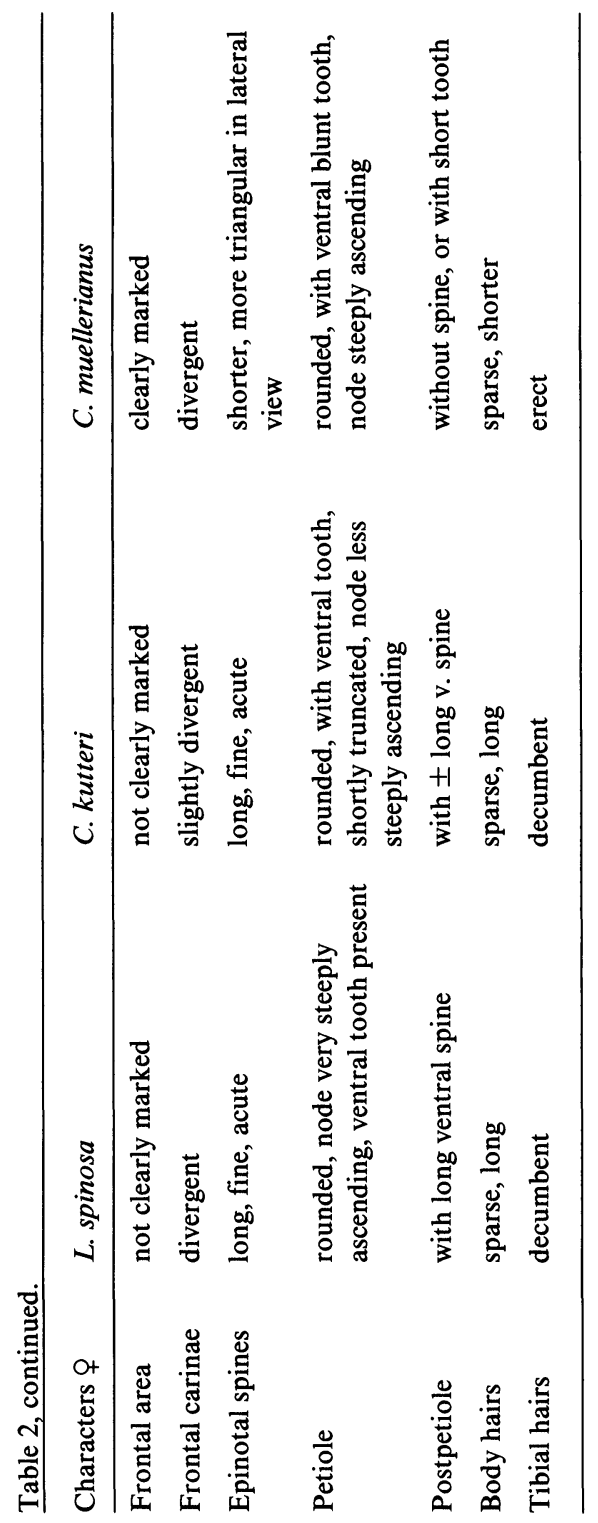


synonymized with the genus Chalepoxenus Menozzi 1922. A morphological comparison of the Leonomyrma holotype $q$ and an allotype $\widehat{\delta}$ with material of Chalepoxenus muellerianus and C. kutteri revealed a close similarity in most relevant characters. It may be predicted that Chalepoxenus spinosus (nov. comb.) will be a slavemaking ant like the other species of the genus.

\section{ACKNOWLEDGEMENTS}

I am indebted to Dr. A. V. Antropov and the Zoological Museum, Moscow, for having provided the type material of Leonomyrma spinosa. The Deutsche Forschungsgeneinschaft has generously supported our studies in Chalepoxenus.

\section{REFERENCES}

ARNOLDI, K. V.

1968. Wichtige Ergänzungen zur Myrmecofauna (Hymenoptera, Formicidae) der USSR, mit einigen Neubeschreibungen (in Russian, German Summary). Zool. J. 47: 1800-1822.

Buschinger, A., W. Ehrhardt, K. Fischer, AND J. Ofer

(in prep.) Biosystematic revision of the slavemaking ant genus Chalepoxenus.

Cagniant, $\mathrm{H}$.

1983. Contribution à la connaissance des Fourmis Marocaines Chalepoxenus tramieri, nov. sp.. Nouv. Rev. Ent. 13: 319-322.

1985. Contribution à la connaissance des Fourmis Marocaines: Chalepoxenus brunneus n.sp. (Hymenoptera, Myrmicidae). Nouv. Rev. Ent. (N.S.) 2, Fasc. 2: 141-146.

EHRHARDT, W.

1982. Untersuchungen zum Raubzugverhalten der sozialparasitischen Ameise Chalepoxenus muellerianus (Finzi) (Hym., Formicidae). Zool. Anz. 208: 145-160.

FinZI, B.

1921. Primo contributo alla conoscenza della fauna mirmecologica della Venezia Giulia. Boll. Soc. Ent. Ital. 53: 118-120.

KUTTER, $\mathrm{H}$.

1973. Zur Taxonomie der Gattung Chalepoxenus (Hymenoptera, Formicidae, Myrmicinae). Mitt. Schweiz. Ent. Ges. 46: 269-280.

Menozzi, C.

1922. Nota su un genere e nuova specie di Formica parassita. Atti Soc. Ital. Sci. Nat. 61: 256-260.

MƯlLER, G.

1923. Le formiche della Venezia Giulia e della Dalmazia. Boll. Soc. Adriat. Sci. Nat. Trieste 28: 11-180. 

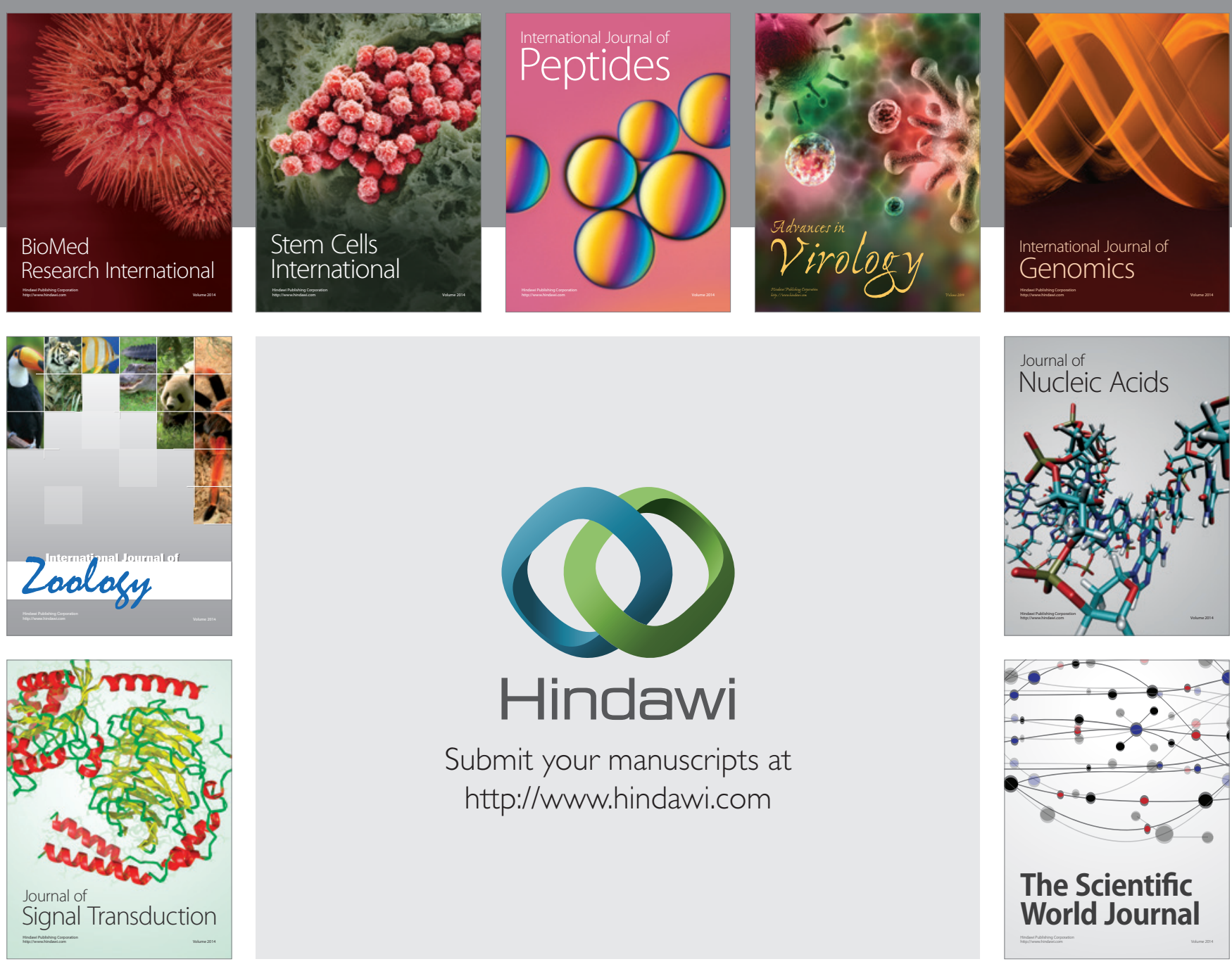

Submit your manuscripts at

http://www.hindawi.com
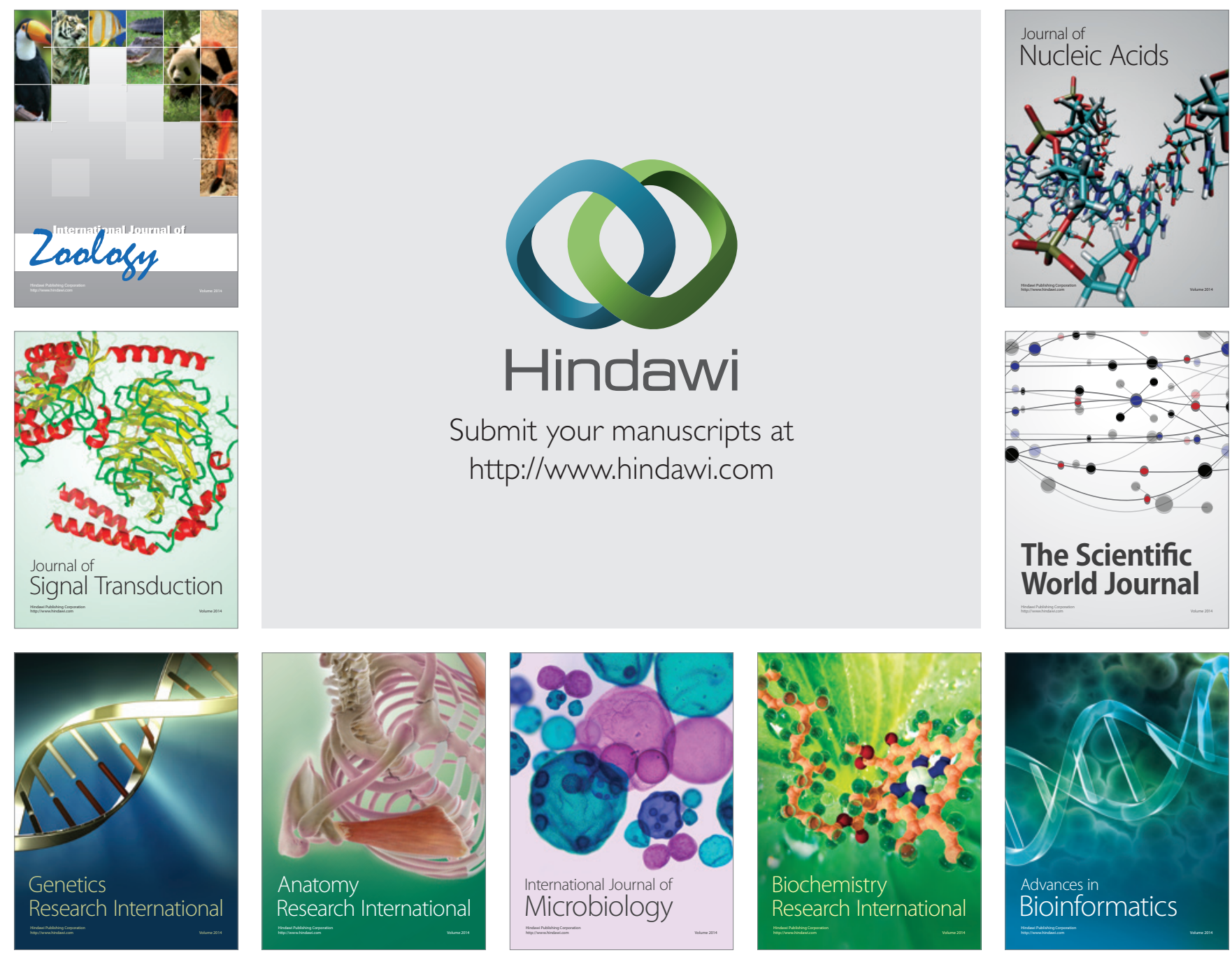

The Scientific World Journal
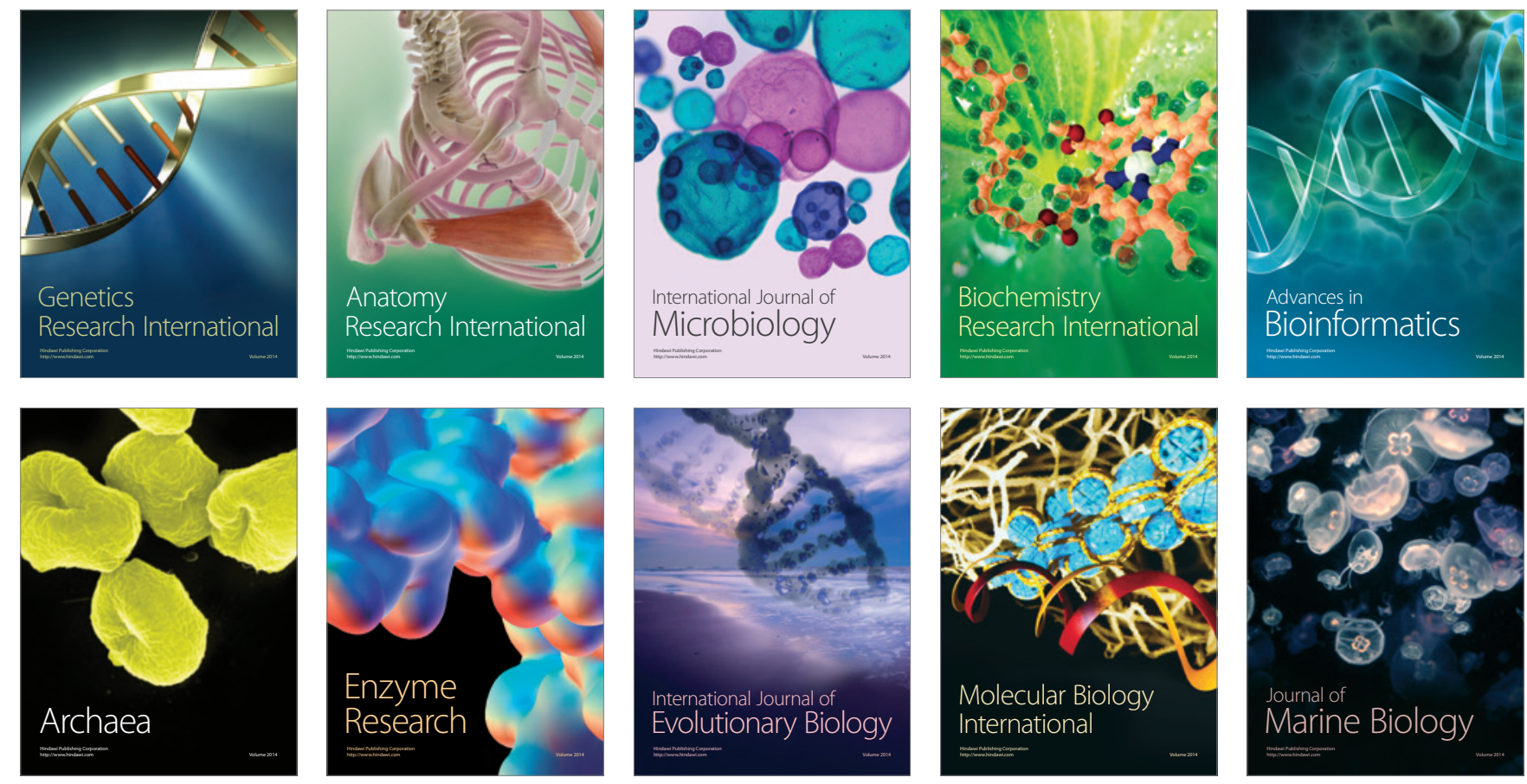